\title{
PENGARUH PERBANDINGAN TEPUNG TALAS BOGOR (Colocasia esculenta L. Schott) DENGAN TEPUNG UBI JALAR ORANYE (Ipomea Batatas L) DAN WAKTU FERMENTASI TERHADAP KARAKTERISTIK CRACKERS SAYURAN
}

\author{
Hasnelly, Ina Siti Nurminabari, Audina Meiliawati \\ Program Studi Teknologi Pangan, Fakultas Teknik, Universitas Pasundan, Jl. Dr.Setiabudi No 93, Bandung, 40153, \\ Indonesia \\ E-mail : hasnelly@unpas.ac.id
}

\begin{abstract}
Abstrak
Tujuan penelitian ini adalah untuk mengetahui pengaruh perbandingan tepung talas Bogor dengan tepung ubi jalar oranye dan waktu fermentasi terhadap karakteristik crackers sayuran. Metode penelitian dilakukan dalam dua tahap, yaitu penelitian pendahuluan dan penelitian utama. Penelitian pendahuluan yang dilakukan adalah menganalisis kadar air, kadar oksalat, dan uji sifat amilografi pada bahan baku serta menentukan formulasi terbaik Pada penelitian utama digunakan Rancangan Acak Kelompok (RAK) Rancangan perlakuan yang dilakukan pada penelitian ini terdiri dari dua faktor yaitu faktor pertama adalah perbandingan tepung talas Bogor dengan tepung ubi jalar oranye $(\mathrm{t})$ terdiri dari t1 $(3: 70, \mathrm{t} 2(1: 1)$, t3 (7:3) faktor kedua adalah waktu fermentasi (f) terdiri dari f1 (20 menit), f2 (40menit), f3 (60 menit). Rancangan respon dalam penelitian ini adalah organoleptik terhadap warna, rasa, aroma, kerenyahan, dan respon kimia yang meliputi analisis kadar air, kadar abu, kadar karbohidrat, kadar lemak, kadar protein dan kadar serat serta sampel terpilih dilakukan analisis betakaroten. Hasil penelitian pendahuluan menunjukkan bahwa kandungan oksalat pada talas $56,14 \mathrm{mg} / 100 \mathrm{~g}$, pada tepung talas $8,68 \mathrm{mg} / \mathrm{g}$, kadar air tepung talas 4,97\%, kadar air tepung ubi jalar 6,5\%, Peak Viscosity tepung campuran terjadi pada suhu $94^{\circ} \mathrm{C}$ selama 5 menit dan formulasi terpilih yaitu formulasi tiga. Hasil penelitian utama menunjukkan bahwa perbandingan tepung talas Bogor dengan tepung ubi jalar oranye dan waktu fermentasi tidak berpengaruh terhadap kadar karbohidrat dan kadar lemak dari crackers sayuran tetapi mempengaruhi warna, rasa, aroma, kerenyahan, kadar air, kadar abu, kadar protein, dan kadar serat. Berdasarkan hasil pemilihan sampel terpilih yang didapatkan yaitu pada perlakuan $\mathrm{t}_{2} \mathrm{f}_{1}$ (perbandingan tepung talas Bogor dengan tepung ubi jalar oranye 1:1 dan waktu fermentasi selama 20 menit) dengan nilai rata-rata warna 3,80, rasa 3,80, aroma 4,00, kerenyahan 4,10, kadar air 4,58\%, kadar abu 1,5\%, kadar lemak $11,87 \%$, kadar protein $11,82 \%$, karbohidrat $60,97 \%$, kadar serat 6,19\% dan betakaroten $19,3902 \mathrm{ppm}$.
\end{abstract}

\begin{abstract}
The purpose of this research was to determine the effect of the comparison of Bogor taro flour with orange sweet potato flour and fermentation time on the characteristics of vegetable crackers. The research method were conducted two stages, namely preliminary research and main research. Preliminary research conducted were analyzing water content, oxalate content, and amylography properties test on raw materials and determining the best formulation. In the main research used Randomized Block Design (RBD). The treatment design carried out in this study consisted of two factors, the first factor was the comparison of Bogor taro flour with orange sweet potato flour (t) consisting of t1 (3:70, t2 (1: 1), t3 (7: 3), the second factor was the fermentation time (f) consisting of $\mathrm{f} 1$ (20 minutes), f2 (40 minutes ), $\mathrm{f} 3$ (60 minutes). The response design in this study was organoleptic on color, taste, aroma, crispness, and chemical response including analysis of water content, ash content, carbohydrate content, fat content, protein content and fiber content as well as beta-carotene analysis on selected sample. The results of preliminary research showed that oxalate content in taro $56.14 \mathrm{mg} / 100 \mathrm{~g}$, in taro flour $8.68 \mathrm{mg} / \mathrm{g}$, water content of taro flour $4.97 \%$, moisture content of sweet potato flour $6.5 \%$. Peak Viscosity of mixed flour occurred at temperature $94 \mathrm{oC}$ for 5 minutes and the selected formulation was formulation three. The results of the main research showed that the comparison of Bogor taro flour with orange sweet potato flour and fermentation time did not affect the carbohydrate content and fat content of vegetable crackers but affected color, taste, aroma, crispness, moisture content, ash content, protein content, and fiber content. Based on the selection results of selected samples which were obtained in the $\mathrm{t} 2 \mathrm{f} 1$ treatment (comparison of Bogor taro flour with orange sweet potato flour 1: 1 and fermentation time for 20 minutes) with an average value of color 3.80, taste 3.80, aroma 4.00, crispy 4.10, water content $4.58 \%$, ash content $1.5 \%$, fat content $11.87 \%$, protein content $11.82 \%$, carbohydrate $60.97 \%$, fiber content $6.19 \%$ and beta-carotene $19.3902 \mathrm{ppm}$.
\end{abstract}

Keywords: crackers, Bogor taro flour, orange sweet potato flour, fermentation time, beta-carotene 


\section{Pendahuluan}

Industri pangan di Indonesia masih memiliki ketergantungan pada tepung terigu, seperti dalam pembuatan mie, biskuit, roti dan cookies. Tepung terigu yang berbahan baku gandum ini tidak dapat diproduksi di Indonesia, karena jenis serealia ini tidak dapat tumbuh di Indonesia. Untuk memanfaatkan bahan baku lokal dapat diatasi dengan menggunakan talas Bogor (Colocasia esculenta L. Schott) dan ubi jalar oranye (Ipomea Batatas) yang digunakan sebagai tepung.

Talas sering dikonsumsi sebagai bahan makanan pokok pengganti gandum. Konsumsi umbi-umbian sebagai sumber karbohidrat selain gandum dan bahan pangan lain yang mengandung gluten dapat mereduksi Coeliac Disease (CD) atau reaksi hipersensitif lainnya (Rekha dan Padmaja, 2002).

Talas memiliki kandungan amilosa yang tinggi (20$25 \%$ ), patinya yang sangat kecil, yaitu antara 1-5 $\mu \mathrm{m}$ dalam umbi talas sangat mudah dicerna dengan bantuan $\alpha$-amylase dalam air liur menjadi gula sederhana, sehingga umbi talas sangat

cocok menjadi bahan makanan terutama untuk balita yang menderita alergi makanan dan orang dewasa yang mengalami gangguan pencernaan (Onwueme, 1978).

Talas memiliki kandungan zat gizi yang cukup tinggi seperti pati $(18.02 \%)$, gula $(1.42 \%)$, kalsium $(0.028 \%)$, dan fosfor $(0.061 \%)$ (Muchtadi dan Sugiyono, 1992). Kandungan zat gizi yang tertinggi dalam talas adalah pati (Hartati dan Prana, 2003).

Umbi talas dapat diolah menjadi tepung talas. Tepung talas dapat menghasilkan produk yang lebih awet karena daya mengikat airnya yang kurang. Tepung talas mengandung gizi yang cukup tinggi dibandingkan umbiumbian lainnya. Kandungan kalsium $(\mathrm{Ca})$ dan posfor $(\mathrm{P})$ tepung talas cukup tinggi dan lebih tinggi dibanding tepung beras, dimana kandungan kalsium pada tepung talas adalah 0,028 sedangkan pada tepung beras adalah 0,006 (Richana, 2012).

Tepung merupakan bentuk jadi hasil pengolahan bahan yang dilakukan dengan metode penggilingan untuk memperkecil ukuran bahan. Tepung berdaya awet tinggi karena memiliki kadar air yang rendah. Salah satu solusi bahan pensubstitusi terigu yang memiliki peluang yang cukup besar dikembangkan adalah talas Bogor (Colocasia esculenta L.Schoott).

Tepung talas memiliki beberapa keuntungan yaitu daya awet, mudah diaplikasikan untuk bermacam-macam produk serta mudah penyimpanannya. Penepungan talas juga mengurangi kerugian karena panen raya.

Tepung talas cocok untuk membuat cookies karena berdasarkan hasil peneliti sebelumnya tepung talas dapat menggantikan fungsi tepung $100 \%$, yang berarti dapat menggantikan tepung terigu secara keseluruhan. Cookies memiliki teksur yang rapuh dan ringan, dan mampu membentuk struktur yang dapat mempertahankan bentuk cookies (Hamidah dan Purwanti).

Indonesia adalah negara penghasil ubi jalar terbesar kedua di dunia setelah RRC, Indonesia memiliki potensi besar dalam pengembangan industri pengolahan berbasis ubi jalar. Menurut data statistik, tingkat produksi ubi jalar di Indonesia pada tahun 2007 mencapai 1,886 juta ton dengan areal panen seluas 176,93 ribu ha (BPS, 2008).

Varietas ubi jalar berdasarkan warnanya dikelompokkan menjadi 4 golongan yaitu ubi jalar putih, ubi jalar kuning, ubi jalar oranye, dan ubi jalar ungu. Ubi jalar yang daging umbinya berwarna kuning, banyak mengandung betakaroten. Warna kuning dari ubi jalar ini dapat berfungsi sebagai pewarna alami yang berasal dari umbi-umbian (Setyawan, 2015).

Umbi talas dan ubi jalar oranye akan menjadi bahan baku crackers dengan menambahkan parutan wortel, daun seledri, dan bahan tambahan lain yang berfungsi untuk menambah nilai gizi dan nilai kesukaan crackers sayuran serta ditambahkan daging ikan lele sebagai sumber protein pada crackers.

Crackers adalah jenis biskuit yang terbuat dari adonan keras, melalui proses fermentasi atau pemeraman, berbentuk pipih yang rasanya lebih ke arah rasa asin dan renyah serta bila dipatahkan penampang potongannya berlapis-lapis (Departemen Perindustrian, 1990).

Salah satu proses yang penting dalam pembuatan crackers adalah fermentasi. Menurut Fardiaz, dkk., (1989), tujuan fermentasi adalah untuk proses pematangan adonan, sehingga adonan mudah ditangani dan dapat menghasilkan produk bermutu baik. Selain itu, fermentasi berperan dalam pembentukan cita rasa crackers dan tekstur yang baik.

\section{Bahan dan Metode Penelitian}

Bahan-bahan yang digunakan dalam proses pengolahan crackers sayuran yaitu talas Bogor varietas ketan yang diperoleh dari Pasar Caringin, ubi jalar oranye varietas beta 1 yang diperoleh dari Balai Penelitian Kacang dan Umbi yang berada di Kota Malang, Ikan Lele Sangkuriang yang diperoleh dari Sri Bandung Lele Organik, lemak nabati merk Blue Band, ragi merk Fermipan, baking powder merk Kupu-kupu, gula jagung, garam Cap Kapal, susu beras, wortel organik dan daun seledri organik yang diperoleh dari Setiabudhi Market.

Bahan-bahan yang digunakan untuk analisis dalam penelitian yaitu aquadest, Asam Klorida $(\mathrm{HCl}) 6 \mathrm{M}, 0.1 \mathrm{~N}$, garam kjedhal, selenium, Asam Sulfat (H2SO4 ) pekat, $2 \%$ Kalium Iodida (KI), Natrium Hidroksida $(\mathrm{NaOH})$ $0.1 \mathrm{~N}, 30 \%$, Kalium Permanganat (KMnO4) 0.05M, NHeksan, larutan luff schoorl, Natrium Sulfit (Na2S2O3), $0,1 \mathrm{~N}$, Natrium Sulfat (Na2SO4,), anhidrat, Merkuri Oksida $(\mathrm{HgO})$, butir granul $\mathrm{Zn}$, dan indikator Phenolpthalein, indikator metil merah, Ammonium Hidroksida (NH4OH), Kalsium Klorida $(\mathrm{CaCl}) 5 \%$, NHexan, potreleum eter, aseton, alumina.Alat yang digunakan dalam pembuatan minuman Edamuberry adalah neraca digital, blender, kain waring, kompor gas, cup plastik, sendok, lemari pendingin, gelas ukur, dan toples. 
Alat-alat yang digunakan dalam proses pengolahan crackers sayuran yaitu alat pemasakan, tray, cabinet dryer, ayakan (80 mesh), food processor, oven, rolling pin.

Alat yang digunakan untuk analisis dalam penelitian ini diantaranya adalah oven merk Yoshino, desikator, neraca analitik merk Mettler Toledo, tanur merk Thermolyne, Table Cap Centrifuge, model PLC-03 soxhlet, vortex, waterbath merk Julabo Twb 12, seperangkat alat kjeldahl, spektrofotometer uv-vis, kolom kromatografi, labu Erlenmeyer $250 \mathrm{ml}$ merk Pyrex, , pipet ukur $10 \mathrm{ml}, 15 \mathrm{ml}$ merk pyrex, labu takar $100 \mathrm{ml}, 250 \mathrm{ml}$ merk Herma, labu Erlenmeyer $250 \mathrm{ml}$ merk Pyrex, filler, botol aquadest, buret, gelas kimia merk Pyrex, gelas ukur merk Pyrex, corong merk Pyrex, kertas saring whatman, batang pengaduk, labu dasar bulat, kaca arloji, cawan petri, inkubator, dan Brookfield (RVA,DV-II Pro).

Penelitian yang akan dilakukan dibagi dalam 3 tahap tahap, Pembuatan Tepung Talas Bogor dan Tepung Ubi Jalar Oranye

Pada penelitian tahap I pembuatan tepung talas Bogor dan tepung ubi jalar oranye, tepung yang telah dibuat dilakukan analisis kimia. Pada tepung talas Bogor dilakukan analisis kimia yang meliputi analisis kadar air, analisis kalsium oksalat pada umbi talas dan tepung talas, dan pada tepung ubi jalar oranye dilakukan analisis kadar air, serta dilakukan analisis amilografi tepung campuran (tepung talas Bogor dan tepung ubi jalar oranye).

Pada tahap II dilakukan untuk menentukan formulasi crackers sayuran yang tepat. Pada penelitian pendahuluan ini dilakukan pembuatan crackers sayuran dengan menggunakan 3 formula, dapat dilihat pada Tabel 1.

Tabel 1. Formulasi Crackers Sayuran Penelitian Tahap I

\begin{tabular}{cccc}
$\begin{array}{c}\text { Bahan Baku } \\
\text { dan } \\
\text { Penunjang }\end{array}$ & $\begin{array}{c}\text { Formulasi } \\
\text { I }\end{array}$ & $\begin{array}{c}\text { Formulasi } \\
\text { II }\end{array}$ & $\begin{array}{c}\text { Formulasi } \\
\text { III }\end{array}$ \\
\hline Tepung Talas & $20 \%$ & $20 \%$ & $20 \%$ \\
\hline $\begin{array}{c}\text { Tepung Ubi } \\
\text { Jalar }\end{array}$ & $20 \%$ & $20 \%$ & $20 \%$ \\
\hline Lemak Nabati & $11,5 \%$ & $10 \%$ & $10 \%$ \\
\hline Ragi & $1,6 \%$ & $2 \%$ & $1,5 \%$ \\
\hline Baking Powder & $1,03 \%$ & $1,2 \%$ & $1 \%$ \\
\hline Gula Jagung & $1,3 \%$ & $1 \%$ & $1,2 \%$ \\
\hline Garam & $1,75 \%$ & $0,2 \%$ & $0,6 \%$ \\
\hline Susu Beras & $12,5 \%$ & $11,5 \%$ & $12 \%$ \\
\hline Wortel & $12 \%$ & $14 \%$ & $12,3 \%$ \\
\hline Daun Seledri & $4,4 \%$ & $6 \%$ & $5,5 \%$ \\
\hline Ikan Lele & 13,90 & 14,1 & 15,9 \\
\hline Total & $\mathbf{1 0 0 \%}$ & $\mathbf{1 0 0 \%}$ & $\mathbf{1 0 0 \%}$
\end{tabular}

Sumber : modifikasi dari Manoppo, dkk., (2012)

Formulasi crackers sayuran terpilih ditentukan dengan uji organoleptik dengan penilaian uji hedonik meliputi atribut warna, rasa, aroma, tekstur dan kerenyahan yang dinilai oleh 30 panelis dan data yang diperoleh dianalisis menggunakan analisis variansi (ANAVA) dan uji lanjut Duncan's untuk mendapatkan kesimpulan. Crackers sayuran yang paling banyak dipilih menurut tingkat kesukaan panelis akan dijadikan acuan dalam penelitian utama. . Kriteria skala hedonik dapat dilihat pada Tabel 2.

\section{Tabel 2. Kriteria Skala Hedonik}

\begin{tabular}{cc} 
Skala Numerik & Skala Hedonik \\
\hline 1 & Sangat tidak suka \\
2 & Tidak suka \\
3 & Agak tidak suka \\
4 & Agak suka \\
5 & Suka \\
6 & Sangat Suka
\end{tabular}

Sumber : Kartika,dkk., 1987

Pada penelitian tahap III, rancangan perlakuan yang digunakan dalam penelitian ini terdiri dari dua faktor, yaitu perbandingan tepung talas dengan ubi jalar (T) dan waktu fermentasi $(\mathrm{F})$ masing-masing perlakuan terdiri atas tiga taraf. Faktor perbandingan tepung talas dengan tepung ubi jalar oranye $(\mathrm{T})$, terdiri dari tiga taraf yaitu :

$\mathrm{t} 1=3: 7$

$\mathrm{t} 2=1: 1$

$\mathrm{t} 3=7: 3$

Faktor waktu fermentasi $(\mathrm{F})$, terdiri dari tiga taraf yaitu: $\mathrm{f} 1=20$ menit

$\mathrm{f} 2=40$ menit

$\mathrm{f} 3=60$ menit

Rancangan percobaan yang digunakan pada penelitian utama ini adalah Rancangan Acak Kelompok (RAK) pola faktorial (3x3) dengan 3 kali ulangan untuk setiap kombinasi perlakuan sehingga diperoleh 27 perlakuan.

Rancangan respon yang akan dilakukan pada penelitian ini meliputi respon organoleptic dengan melakukan penilaian terhadap warna, rasa, aroma, dan kerenyahan, dengan menggunakan preference test (skala hedonik) dengan 30 orang panelis. Hasil uji hedonik digunakan untuk menilai karakteristik fisik dan mutu crackers sayuran menurut panelis berdasarkan nilai rataan setiap parameter masing-masing formula. Formula terbaik ditentukan berdasarkan hasil rata-rata uji hedonik tertinggi yaitu dengan melihat persentase penerimaan setiap formula. Respon kimia meliputi penentuan kadar karbohidrat dengan metode Luff-Schoorl (AOAC, 2010), kadar air dengan metode gravimetri (AOAC, 2010), kadar protein dengan metode Kjedahl (AOAC, 2010), kadar lemak dengan metode Sohxlet (AOAC, 2010), kadar abu dengan metode gravimetri (AOAC, 1995) kadar serat dengan metode gravimetri (AOAC, 2010), serta untuk sampel terpilih dilakukan analisis kadar betakaroten (AOAC, 2005). 


\section{Hasil dan Pembahasan}

\section{Penelitian Pendahuluan}

1. Analisis Bahan Baku

Hasil analisis bahan baku dapat dilihat pada Tabel 1.

Tabel 1. Data Hasil Analisis Bahan Baku

\begin{tabular}{ll}
\hline \multicolumn{1}{c}{ Analisis } & \multicolumn{1}{c}{ Hasil Analisis } \\
\hline Kadar Oksalat Talas Bogor & $56,14 \mathrm{mg} / 100 \mathrm{~g}$ \\
\hline Kadar Oksalat Tepung Talas Bogor & $8,69 \mathrm{mg} / 100 \mathrm{~g}$ \\
\hline Kadar Air Tepung Talas Bogor & $4,97 \%$ \\
\hline Kadar Air Tepung Ubi Jalar Oranye & $6,5 \%$ \\
\hline
\end{tabular}

Asam oksalat/oksalat adalah senyawa kimia yang memiliki rumus $\mathrm{H} 2 \mathrm{C} 2 \mathrm{O} 4$ dengan nama sistematis asam etanadioat. Banyak ion logam yang membentuk endapan tak larut dengan asam oksalat, contoh terbaik adalah kalsium oksalat (CaOOC-COOCa), penyusunan utama jenis batu ginjal yang sering ditemukan.

Menurut Kurdi (2002), kristal kalsium oksalat pada talas terdapat dalam dua bentuk yaitu druse (bentuk bulat) dan raphide (seperti jarum halus), yaitu sekitar 80 sampai dengan 85 persen dari total kandungan kalsium oksalat.

Senyawa oksalat pada talas Bogor perlu dianalisis dahulu sebelum proses penepungan untuk mengetahui kadarnya. Talas Bogor ditambah dengan air dan $\mathrm{HCl}$ untuk mengesktrak senyawa oksalatnya. Asam oksalat akan larut dalam air, sedangkan kalsium oksalat akan larut dengan $\mathrm{HCl}$. Proses tersebut dibantu dengan pemanasan untuk mempercepat proses pelarutan. Pemanasan dapat merusak dinding sel sehingga kalsium oksalat akan lebih cepat keluar dan larut (Maulina et al., 2012).

Berdasarkan pada Tabel 1 kadar oksalat yang terdapat pada talas Bogor adalah sebesar $56,14 \mathrm{mg} / 100 \mathrm{~g}$ Kadar oksalat yang terdapat pada talas Bogor ini masih dibawah batas maksimum yaitu 70-100mg/100g.

Pengujian kadar oksalat tepung talas Bogor dilakukan untuk mengetahui kadar oksalat setelah dilakukan perendaman menggunakan garam $10 \%$ selama 1 jam. Berdasarkan pada Tabel 1 kadar oksalat yang terdapat pada tepung talas Bogor adalah sebesar 8,69 $\mathrm{mg} / 100 \mathrm{~g}$. Kadar oksalat yang terdapat pada tepung talas Bogor ini masih dibawah batas maksimum yaitu 70$100 \mathrm{mg} / 100 \mathrm{~g}$.

Garam mampu membuat senyawa kalsium oksalat dalam sel terdesak keluar, karena proses osmosis yang terus menerus, sedangkan asam oksalatnya akan larut dalam air (Amalia dan Yuliana, 2013). Larutan garam tersebut akan terionisasi menjadi $\mathrm{Na}+$ dan $\mathrm{Cl}-$, dan bereaksi menjadi natrium oksalat dan endapan kalsium klorida yang larut dalam air (Chotimah dan Fajarini, 2013). Reaksi selengkapnya dapat dilihat sebagai berikut.

$\mathrm{NaCl}+\mathrm{CaC} 2 \mathrm{O} 4 \rightarrow \mathrm{Na} 2 \mathrm{C} 2 \mathrm{O} 4+\mathrm{CaCl}$

Berdasarkan hasil analisis kadar air menggunakan metode gravimetri, kadar air yang terkandung pada tepung talas Bogor adalah sebesar 4,97\%. Menurut Apriyani., dkk (2011) kadar air tepung talas sebesar
$5,72 \%$, perbedaan kadar air ini dipengaruhi oleh umur talas, jenis talas, dan ketebalan pengirisan.

Menurut Standar Nasional Indonesia (SNI No. 3751 : 2009) tentang tepung terigu, syarat mutu kadar air untuk tepung adalah maksimal $14,5 \%$. Maka tepung talas Bogor telah memenuhi Standar Nasional Indonesia karena kadar air tepung talas Bogor yang dihasilkan memiliki kadar air 4,97\%.

Berdasarkan hasil analisis kadar air menggunakan metode gravimetri, kadar air yang terkandung pada tepung ubi jalar oranye adalah sebesar 6,5\%. Menurut SNI (1996) kadar air tepung ubi jalar oranye adalah maksimal 15\%. Maka tepung ubi jalar oranye telah memenuhi Standar Nasional Indonesia karena kadar air tepung ubi jalar oranye yang dihasilkan memiliki kadar air sebesar $6,5 \%$.

2. Uji Amilograf Tepung Campuran 1:1 (Tepung Talas Bogor : Tepung Ubi Jalar Oranye)

Sifat fisiko kimia atau amilograf pati ditentukan berdasarkan perubahan viskositas pati pada proses pemanasan dengan menggunakan Rapid Visco Analyzer. Hasil analisis sifat amilograf tepung campuran $1: 1$ (tepung talas bogor : tepung ubi jalar oranye) dapat dilihat pada Gambar 15 dan amilogram yang diperoleh akan memberikan data-data seperti yang tertera pada Tabel 2.

Tabel.2 Data Amilogram Tepung Campuran 1: 1 (Tepung Talas Bogor : Tepung Ubi Jalar Oranye)

\begin{tabular}{lcccccc}
\hline Keterangan & PT $\left({ }^{\circ} \mathrm{C}\right)$ & $\begin{array}{c}\text { PV } \\
(\mathrm{cP})\end{array}$ & HV $(\mathrm{cP})$ & $\begin{array}{c}\text { FV } \\
(\mathrm{cP})\end{array}$ & $\begin{array}{c}\text { BD } \\
(\mathrm{cP})\end{array}$ & $\begin{array}{c}\text { SV } \\
(\mathrm{cP})\end{array}$ \\
\hline Rata-rata & 78,23 & 1431,5 & 850,5 & 1131,5 & 581 & 281 \\
\hline Keterangan : & \\
PT = Pasting Temperature (Suhu awal gelatinisasi) & & \\
$\mathrm{PV}=$ Peak Viscosity (Viskositas puncak) \\
HV = Hold Viscosity(Viskositas pada suhu $95^{\circ} \mathrm{C}$ setelah 5 menit) \\
FV = Final Peak Viscosity(viskositas pada suhu 50 $50^{\circ} \mathrm{C}$ setelah 5 menit) \\
BD = Breakdown (Perubahan viskositas selama pemanasan atau PV - \\
HV) \\
SV = SetbackViscosity
\end{tabular}

Suhu awal gelatinisasi (PT) merupakan suhu dimana granula tepung mulai menyerap air dapat dilihat dengan mulai meningkatnya viskositas. Suhu awal gelatinisasi tepung campuran yang dihasilkan adalah $78,23^{\circ} \mathrm{C}$. Suhu gelatinisasi dipengaruhi oleh beberapa faktor, antara lain ukuran molekul amilosa dan amilopektin serta keadaan media pemanasan. Kadar lemak atau protein yang tinggi mampu membentuk kompleks dengan amilosa sehingga membentuk endapan yang tidak larut dan menghambat pengeluaran amilosa dari granula. Dengan demikian diperlukan energi yang lebih besar untuk melepas amilosa sehingga suhu awal gelatinisasi yang dicapai akan lebih tinggi (Glicksman 1969 dalam Richana dan Sunarti 2004). Suhu awal gelatinisasi tepung talas termasuk tinggi, hal ini dapat diakibatkan oleh kandungan protein tepung talas yang cukup tinggi. Menurut Shin dan Ahn (1983), suhu awal gelatinisasi tepung ubi jalar adalah $65-80 \mathrm{oC}$ 
Peak viscosity atau viskositas puncak menunjukkan kondisi awal tepung tergelatinisasi atau mencapai pengembangan maksimum hingga selanjutnya akan pecah.Viskositas puncak pada tepung talas adalah 1431,5 cP. Suhu dimana viskositas maksimum tercapai disebut suhu akhir gelatinisasi. Pada suhu ini granula pati telah kehilangan sifat birefringence-nya dan granula sudah tidak mempunyai kristal lagi. Komponen yang menyebabkan sifat kristal dan birefringence adalah amilopektin. Pada waktu granula mulai pecah karena suhu tinggi sifat ini akan hilang yang menyebabkan $90 \%$ butir pati dalam air panas membengkak sehingga tidak kembali ke bentuk normalnya (Winarno, 2004). Menurut Kafah, dkk., (2012) Viskositas puncak pada tepung talas adalah $2865.3 \mathrm{cP}$, seangkan menurut Polnay, dkk., (2015) viskositas puncak pada ubi jalar oranye adalah $1.347 \mathrm{cP}$.

Break down atau penurunan viskositas selama pemanasan menunjukkan kestabilan pasta selama pemanasan, dimana semakin rendah breakdown maka pasta yang terbentuk akan semakin stabil terhadap panas. Penurunan viskositas yang terjadi selama pemanasan bernilai $581 \mathrm{cP}$.

Setback atau perubahan viskositas selama pendinginan. Semakin tingginya nilai setback maka menunjukkan semakin tinggi pula kecenderungan untuk membentuk gel (meningkatkan viskositas) selama pendinginan. Perubahan viskositas yang terjadi selama pendinginan sebesar $281 \mathrm{cP}$. Nilai setback menandakan tingginya kecenderungan untuk terjadinya retrogradasi. Fenomena retrogradasi pati disebabkan oleh terjadinya pembentukan kembali ikatan hidrogen antar molekul amilosa dan amilopektin.

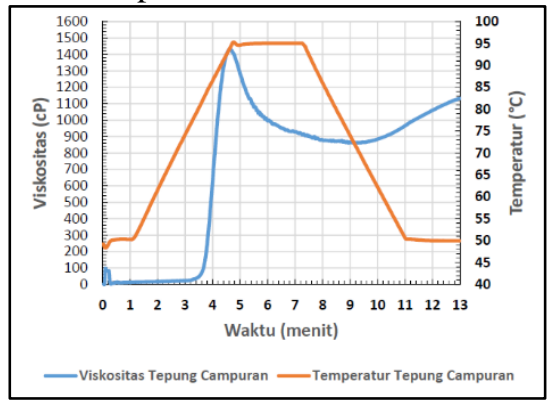

Gambar 1. Grafik Amilografi Tepung Campuran 1:1 (Tepung Talas dan Tepung Ubi Jalar Oranye)

Berdasarkan Gambar 1 dapat dilihat bahwa Peak Viscosity tepung campuran terjadi pada suhu 94oC selama 5 menit, maka suhu pemanggangan yang digunakan pada crackers sayuran ini harus melebihi suhu 94oC dengan waktu lebih dari 5 menit agar tercapai tekstur renyah yang diinginkan.

3. Penentuan Formulasi

Hasil analisis variansi (ANAVA) menunjukkan bahwa formulasi berpengaruh terhadap warna, rasa dan aroma pada crackers sayuran, sedangkan tekstur dan kerenyahan tidak berpengaruh. Perbedaan tiap perlakuan dapat dilihat pada Tabel 3.
Tabel 3. Hasil Organoleptik Uji Hedonik Penelitian Pendahuluan

\begin{tabular}{|c|c|c|c|c|c|}
\hline \multirow{2}{*}{ Formulasi } & \multicolumn{5}{|c|}{ Respon Uji } \\
\hline & Iroma & Rasa & Varna & 'esktur & ierenyahan \\
\hline \multirow{2}{*}{ Formulasi 1} & 3,83 & 3,50 & 3,00 & 4,43 & 4,63 \\
\hline & $\mathrm{a}$ & $\mathrm{a}$ & $\mathrm{a}$ & a & $\mathrm{a}$ \\
\hline \multirow[t]{2}{*}{ Formulasi II } & 4,17 & 4,20 & 5,10 & 4,47 & 4,53 \\
\hline & $\mathrm{b}$ & $\mathrm{b}$ & $\mathrm{c}$ & $\mathrm{a}$ & $\mathrm{a}$ \\
\hline \multirow[t]{2}{*}{ Formulasi III } & 4,70 & 4,63 & 4,20 & 4,63 & 4,67 \\
\hline & $\mathrm{c}$ & $b$ & $b$ & $\mathrm{a}$ & $\mathrm{a}$ \\
\hline
\end{tabular}

Keterangan: Nilai rata-rata yang diikuti huruf berbeda, berbeda nyata menurut uji lanjut Duncan pada taraf nyata $5 \%$.

Berdasarkan hasil penelitian pendahuluan dengan 3 (tiga) formulasi berbeda, dengan dilakukannya respon organoleptik dengan metode hedonik maka didapatkan formulasi perlakuan nomor 3 (tiga) yang terpilih dengan formulasi Tepung Talas 20\%, Tepung Ubi Jalar 20\%, Lemak Nabati 10\%, Ragi 1,5\%, Baking Powder 1\%, Gula Jagung 1,2\%, Garam 0,6\% ,Susu Beras 12\%, Wortel $12,3 \%$, Daun Seledri 5,5\%, dan Ikan Lele $15,9 \%$. Formulasi ini akan digunakan sebagai acuan untuk penelitian utama.

\section{a. Warna}

Penentuan mutu bahan makanan pada umumnya sangat bergantung pada beberapa faktor, diantaranya cita rasa, warna, tekstur, nilai gizi dan sifat mikrobiologis. Faktor warna secara visual tampil terlebih dahulu dan kadang sangat menentukan. Suatu bahan yang dinilai bergizi, enak, dan teksturnya sangat baik tidak akan dimakan apabila memiliki warna yang tidak sedap dipandang, sehingga warna dapat digunakan untuk menentukan mutu (Winarno, 2004).

Warna merupakan salah satu faktor yang mempengaruhi daya terima konsumen terhadap suatu produk, secara visual faktor warna akan tampil terlebih dahulu dan kadang-kadang sangat menentukan sebelum faktor-faktor lain seperti mikrobiologi dan nilai gizi. Suatu bahan yang dinilai bergizi, enak dan memiliki tekstur yang baik tidak akan dikonsumsi bila memiliki warna yang tidak sedap dipandang atau memberikan kesan menyimpang dari warna yang seharusnya (Winarno, 2004).

Berdasarkan hasil Analisis Variansi (ANAVA) pada Tabel 3 menunjukkan bahwa variasi formula berpengaruh terhadap warna crackers sayuran. Pada respon organoleptik atribut warna panelis lebih menyukai formulasi 2 dengan penilaian panelis adalah 4-6 tetapi panelis lebih banyak memberikan nilai 5. Warna crackers sayuran yang dibuat pada penelitian secara umum berwarna kuning kecoklatan.

Formulasi yang berbeda menghasilkan perbedaan yang nyata, hal ini disebabkan karena perbedaan banyaknya jumlah wortel dan daun seledri yang ditambahkan kedalam formulasi. Semakin banyak jumlah wortel dan daun seledri yang ditambahkan maka warna crackers sayuran semakin disukai panelis. Hal ini disebabkan karena semakin banyak jumlah wortel dan 
daun seledri yang ditambahkan maka warna crackers sayuran akan semakin coklat dan hijau.

\section{b. Rasa}

Rasa dalam bahan pangan sangat penting dalam menentukan daya terima konsumen. Selain itu, rasa juga merupakan salah satu faktor yang sangat berpengaruh dalam menentukan mutu. Biasanya rasa sangat diperhatikan oleh konsumen setelah warna. Rasa yang ditimbulkan oleh produk pangan dapat berasal dari bahan itu sendiri juga berasal dari zat - zat yang ditambahkan dari luar saat proses berlangsung, sehingga dapat menimbulkan rasa yang tajam atau setidaknya jadi berkurang (deMan, 1997).

Berdasarkan hasil Analisis Variansi (ANAVA) pada Tabel 3 menunjukkan bahwa variasi formula berpengaruh terhadap rasa crackers sayuran. Rasa crackers sayuran yang dibuat pada penelitian secara umum adalah asin. Pada respon organoleptik atribut rasa panelis lebih menyukai formulasi 3 dengan penilaian panelis adalah 3-6 tetapi panelis lebih banyak memberikan nilai 5 yang berarti panelis menyukai warna crackers sayuran.

Formulasi yang berbeda menghasilkan perbedaan yang nyata, hal ini disebabkan karena perbedaan konsentrasi garam yang ditambahkan, semakin tinggi konsentrasi garam yang ditambahkan semakin tidak disukai panelis dan semakin rendah konsentrasi garam yang ditambahkan semakin tidak disukai panelis.

\section{c. Aroma}

Aroma merupakan faktor yang sangat penting untuk menentukan tingkat penerimaan konsumen terhadap suatu produk, sebab sebelum dimakan biasanya konsumen terlebih dahulu mencium aroma dari produk tersebut untuk menilai layak tidaknya produk tersebut dimakan. Aroma yang enak dapat menarik perhatian, konsumen lebih cenderung menyukai makanan dari aroma. Aroma lebih banyak berhubungan dengan panca indra pembau. Aroma baru dapat dikenali apabila berbentuk uap. Aroma yang diterima oleh hidung dan otak merupakan campuran empat bau utama yaitu harum, asam, tengik, dan hangus. (Winarno, 2004).

Berdasarkan hasil Analisis Variansi (ANAVA) pada Tabel 3 menunjukkan bahwa variasi formula berpengaruh terhadap aroma crackers sayuran. Aroma crackers sayuran yang dibuat pada penelitian secara umum beraroma kuat ubi jalar oranye. Pada respon organoleptik atribut warna panelis lebih menyukai formulasi 3 dengan penilaian panelis adalah 3-6 tetapi panelis lebih banyak memberikan nilai 4 dan 5 yang berarti panelis menyukai aroma crackers sayuran.

Uji organoleptik pada atribut aroma memiliki hasil yang fluktuatif. Hal ini kemungkinan diakibatkan adanya kesalahan psikologis dari panelis yaitu kesalahan tendensi sentral. Karakteristik kesalahan tendensi sentral ini adalah panelis memberikan nilai tengah pada skala nilai yang ada dan ragu-ragu dalam memberikan nilai tertinggi. Efek dari kesalahan ini adalah panelis menganggap semua sampel yang diuji hampir sama (Kartika,dkk., 1987).

c. Tekstur

Berdasarkan hasil Analisis Variansi (ANAVA) pada Tabel 3 menunjukkan bahwa variasi formula berpengaruh terhadap tekstur crackers sayuran. Hal ini dikarenakan pada pembuatan crackers sayuran menggunakan jenis bahan-bahan yang sama serta suhu dan waktu pemanggangan yang sama, sehingga tekstur crackers sayuran yang dihasilkan tidak mempengaruhi secara spesifik respon panelis. Tekstur pada makanan sangat ditentukan oleh kadar air, kandungan lemak, dan jumlah serta jenis karbohidrat dan protein yang menyusunnya (Fellows, 1988).

\section{d. Kerenyahan}

Tekstur pada biskuit (termasuk crackers) meliputi kekerasan, kerenyahan, kemudahan untuk dipatahkan, dan konsistensi pada gigitan pertamanya (Fellows, 1988). Berdasarkan hasil Analisis Variansi (ANAVA) pada Tabel 3 menunjukkan bahwa variasi formula tidak berpengaruh terhadap kerenyahan crackers sayuran. Hal ini dikarenakan pada pembuatan crackers sayuran menggunakan jenis bahan-bahan yang sama serta suhu dan waktu pemanggangan yang sama, sehingga tekstur crackers sayuran yang dihasilkan tidak mempengaruhi secara spesifik respon panelis.

\section{Hasil Penelitian Utama}

1. Uji Organoleptik

a. Warna

Berdasarkan perhitungan analisis variansi diketahui bahwa perbandingan tepung talas Bogor dengan tepung ubi jalar oranye ( $\mathrm{T}$ ) berpengaruh sedangkan waktu fermentasi $(\mathrm{F})$ serta interaksinya $(\mathrm{TF})$ tidak berpengaruh terhadap karakteristik warna crackers sayuran, sehingga dilakukan uji lanjut Duncan untuk metode perbandingan tepung talas Bogor dengan tepung ubi jalar oranye (T). Hasil analisis uji lanjut Duncan terhadap karakteristik warna crackers sayuran dapat dilihat pada Tabel 4.

Tabel 4. Nilai Rata-Rata Perbandingan Tepung Talas Bogor dengan Tepung Ubi Jalar Oranye (T) terhadap Karakteristik Warna Crackers Sayuran

\begin{tabular}{ccc}
$\begin{array}{c}\text { Perbandingan Tepung Talas } \\
\text { Bogor dengan Tepung Ubi Jalar } \\
\text { Oranye (T) }\end{array}$ & $\begin{array}{c}\text { Hasil } \\
\text { Rata-Rata }\end{array}$ & $\begin{array}{c}\text { Taraf } \\
\text { Nyata 5\% }\end{array}$ \\
\hline $\mathrm{t} 1(3: 7)$ & 3.18 & $\mathrm{a}$ \\
\hline $\mathrm{t} 2(1: 1)$ & 3.89 & $\mathrm{~b}$ \\
\hline $\mathrm{t} 3(7: 3)$ & 4.45 & $\mathrm{c}$ \\
\hline
\end{tabular}

Keterangan: Nilai rata-rata yang ditandai dengan huruf yang sama menunjukkan tidak berbeda nyata pada taraf 5\% Uji Duncan.

Berdasarkan Tabel 4 respon panelis terhadap warna crackers menunjukkan nilai yang berkisar antara 3,184,45 yang artinya agak disukai panelis. Hasil penelitian menunjukkan semakin banyak perbandingan tepung ubi jalar oranye, warna crackers sayuran yang dihasilkan 
akan semakin tidak disukai oleh panelis. Hal ini disebabkan karena semakin banyak perbandingan tepung ubi jalar oranye yang ditambahkan, warna crackers sayuran akan semakin gelap.

Tepung ubi jalar oranye memiliki pigmen karotenoid seperti lutein, zea xanthin, dan karoten yang memberikan warna oranye pada ubi jalar oranye (Purwanto, 2013). Panelis kurang menyukai sampel dengan warna yang terlalu kuat ataupun terlalu lemah, panelis cenderung menyukai produk dengan warna khas crackers tetapi tidak terlalu kuat.

Warna crackers yang dihasilkan kuning keemasan, sehingga agak disukai oleh panelis. Penambahan tepung ubi jalar oranye akan menghasilkan warna keemasan yang cenderung gelap dikarenakan warna tepung ubi jalar oranye yang sangat oranye serta pengaruh protein yang bergabung dengan gula atau pati dalam suasana panas akan menyebabkan warna menjadi gelap. Hal ini disebabkan oleh adanya reaksi maillard, yaitu suatu reaksi antara gula atau pati yang menyebabkan warna menjadi gelap (Winarno, 2004).

Warna merupakan salah satu faktor yang menentukan mutu bahan pangan sebelum faktor-faktor lain dipertimbangkan secara visual. Suatu bahan pangan yang bergizi dan tekstur yang baik akan kurang baik jika mempunyai warna yang menyimpang dari warna yang seharusnya. Suatu bahan makanan dinilai bergizi dan enak rasanya namun tidak dimakan apabila memiliki warna yang tidak sedap dipandang atau memberi kesan menyimpang dari warna yang seharusnya. Faktor - faktor yang menyebabkan suatu bahan makanan berwarna adalah pigmen alami yang terdapat dalam bahan pangan tersebut (Winarno, 2004).

\section{b. Rasa}

Rasa dalam bahan pangan sangat penting dalam menentukan daya terima konsumen. Selain itu, rasa juga merupakan salah satu faktor yang sangat berpengaruh dalam menentukan mutu. Biasanya rasa sangat diperhatikan oleh konsumen setelah warna. Rasa yang ditimbulkan oleh produk pangan dapat berasal dari bahan itu sendiri juga berasal dari zat - zat yang ditambahkan dari luar saat proses berlangsung, sehingga dapat menimbulkan rasa yang tajam atau setidaknya jadi berkurang (deMan, 1997).

Berdasarkan perhitungan analisis variansi diketahui bahwa perbandingan tepung talas Bogor dengan tepung ubi jalar oranye $(\mathrm{T})$ berpengaruh, sedangkan waktu fermentasi $(\mathrm{F})$ serta interaksinya (TF) tidak berpengaruh terhadap karakteristik rasa crackers sayuran, sehingga dilakukan uji lanjut Duncan untuk metode perbandingan tepung talas Bogor dengan tepung ubi jalar oranye (T). Hasil analisis uji lanjut Duncan terhadap karakteristik rasa crackers sayuran dapat dilihat pada Tabel 5.

Tabel 5. Nilai Rata-Rata Perbandingan Tepung Talas Bogor dengan Tepung Ubi Jalar Oranye (T) terhadap Karakteristik Rasa Crackers Sayuran
Keterangan : nilai rata - rata yang ditandai dengan huruf yang berbeda menunjukkan perbedaan pada taraf 5\% uji Duncan.

Berdasarkan Tabel 5 respon panelis terhadap rasa

\begin{tabular}{ccc}
\hline $\begin{array}{c}\text { Perbandingan Tepung } \\
\text { Talas Bogor dengan } \\
\text { Tepung Ubi Jalar Oranye } \\
\text { (T) }\end{array}$ & $\begin{array}{c}\text { Hasil } \\
\text { Rata- } \\
\text { Rata }\end{array}$ & Taraf Nyata 5\% \\
\hline t1 (3:7) & 3.37 & $\mathrm{a}$ \\
\hline $\mathrm{t} 2(1: 1)$ & 3.87 & $\mathrm{~b}$ \\
\hline $\mathrm{t} 3(7: 3)$ & 4.27 & $\mathrm{c}$ \\
\hline
\end{tabular}

crackers menunjukkan nilai yang berkisar antara 3,374,27 yang artinya agak disukai panelis. Hasil penelitian menunjukkan semakin banyak perbandingan tepung ubi jalar oranye, rasa crackers sayuran yang dihasilkan akan semakin tidak disukai oleh panelis. Hal ini disebabkan karena pada perbandingan 1:1 rasa tepung ubi jalar oranye sudah cukup dominan, maka ketika perbandingan tepung ubi jalar oranye lebih banyak akan menutupi rasa dari tepung talas Bogor.

\section{c. Aroma}

Aroma lebih banyak berhubungan dengan panca indra pembau. Aroma baru dapat dikenali apabila berbentuk uap. Aroma yang diterima oleh hidung dan otak merupakan campuran empat bau utama yaitu harum, asam, tengik, dan hangus. Aroma merupakan faktor yang sangat penting untuk menentukan tingkat penerimaan konsumen terhadap suatu produk, sebab sebelum dimakan biasanya konsumen terlebih dahulu mencium aroma dari produk tersebut untuk menilai layak tidaknya produk tersebut dimakan. Aroma yang enak dapat menarik perhatian, konsumen lebih cenderung menyukai makanan dari aroma (Winarno, 2004).

Berdasarkan perhitungan analisis variansi diketahui bahwa perbandingan tepung talas Bogor dengan tepung ubi jalar oranye (T), waktu fermentasi (F) serta interaksinya (TF) berpengaruh terhadap karakteristik aroma crackers sayuran, sehingga dilakukan uji lanjut Duncan. Hasil analisis uji lanjut Duncan terhadap karakteristik rasa crackers sayuran dapat dilihat pada Tabel 6.

Tabel 6. Pengaruh Interaksi Perbandingan Tepung Talas Bogor dengan Tepung Ubi Jalar Oranye (T) dan Waktu Fermentasi (F) terhadap Karakteristik Aroma Crackers Sayuran

\begin{tabular}{cccc}
\hline $\begin{array}{c}\text { Perbandingan Tepung } \\
\text { Talas Bogor dengan } \\
\text { Tepung Ubi Jalar } \\
\text { Oranye (T) }\end{array}$ & \multicolumn{3}{c}{ Waktu Fermentasi (F) } \\
\cline { 2 - 4 } & $\begin{array}{c}\mathbf{2 0} \\
\text { menit } \\
(\mathbf{f 1})\end{array}$ & $\begin{array}{c}\mathbf{4 0} \\
\text { menit } \\
\text { (f2) }\end{array}$ & $\begin{array}{c}\mathbf{6 0} \text { menit } \\
(\mathbf{f 3})\end{array}$ \\
\hline $\mathbf{3 : 7}(\mathbf{t} 1)$ & $\begin{array}{c}4,00 \mathrm{~A} \\
\mathrm{c}\end{array}$ & $\begin{array}{c}3,73 \mathrm{~A} \\
\mathrm{~b}\end{array}$ & $\begin{array}{c}3,64 \mathrm{~A} \\
\mathrm{a}\end{array}$ \\
\hline $\mathbf{1 : 1}(\mathbf{t} 2)$ & $4,00 \mathrm{~A}$ & $3,82 \mathrm{~A}$ & $3,79 \mathrm{~B}$ \\
$\mathrm{~b}$ & $\mathrm{a}$ & $\mathrm{a}$ \\
\hline $\mathbf{7 : 3}(\mathbf{t} 3)$ & $4,14 \mathrm{~B}$ & $\begin{array}{c}4,12 \mathrm{~B} \\
\mathrm{a}\end{array}$ & $\begin{array}{c}4,09 \mathrm{C} \\
\mathrm{a}\end{array}$ \\
\hline
\end{tabular}

Keterangan : Huruf kecil dibaca arah horizontal dan huruf besar dibaca arah vertikal. Huruf yang berbeda menyatakan perbedaan yang nyata pada taraf 5\% uji Duncan. 
Berdasarkan Tabel 6 respon panelis terhadap aroma crackers menunjukkan nilai yang berkisar antara 3,644,14 yang artinya agak disukai panelis. Hasil penelitian pengujian atribut aroma menunjukkan semakin lama fermentasi semakin tidak disukai panelis, hal ini disebabkan karena aroma yang semakin menyengat dari proses fermentasi. Hal ini didukung oleh pendapat Darajat,dkk (2014) bahwa waktu fermentasi juga memberikan pengaruh dalam kualitas produk suatu produk, produk fermentasi adalah produk yang dapat diterima baik secara kenampakan, aroma serta nutrisi yang dihasilkan.

Hasil penelitian pengujian atribut aroma juga menunjukkan semakin banyak tepung ubi jalar yang ditambahkan semakin tidak disukai oleh panelis hal ini dikarenakan ubi jalar memiliki aroma yang khas dan sangat dominan.

\section{d. Kerenyahan}

Tekstur pada biskuit meliputi kekerasan, kemudahan untuk dipatahkan, dan konsistensi pada gigitan pertamanya (Fellows, 1988). Lebih lanjut Fellows menerangkan bahwa tekstur pada makanan sangat ditentukan oleh kadar air, kandungan lemak, dan jumlah serta jenis karbohidrat dan protein yang menyusunnya.

Kerenyahan adalah tekstur yang dirasakan oleh indra pencicip. Tekstur makanan didefinisikan sebagai cara penggabungan unsur komponen dan struktur menjadi mikro dan makro struktur dan keluar dalam segi aliran dan deformasi. Kerenyahan secara visual dijadikan karakteristik dalam penilaian suatu bahan makanan oleh konsumen dan faktor penting mutu makanan kering (DeMan,1997).

Berdasarkan perhitungan analisis variansi diketahui bahwa perbandingan tepung talas Bogor dengan tepung ubi jalar oranye (T), waktu fermentasi (F) serta interaksinya (TF) berpengaruh terhadap karakteristik aroma crackers sayuran, sehingga dilakukan uji lanjut Duncan. Hasil analisis uji lanjut Duncan terhadap karakteristik rasa crackers sayuran dapat dilihat pada Tabel 7.

Tabel 7. Pengaruh Interaksi Perbandingan Tepung Talas Bogor dengan Tepung Ubi Jalar Oranye (T) dan Waktu Fermentasi (F) terhadap Karakteristik Kerenyahan Crackers Sayuran

\begin{tabular}{|c|c|c|c|}
\hline \multirow{2}{*}{$\begin{array}{c}\text { Perbandingan Tepung } \\
\text { Talas Bogor dengan } \\
\text { Tepung Ubi Jalar } \\
\text { Oranye (T) }\end{array}$} & \multicolumn{3}{|c|}{ Waktu Fermentasi (F) } \\
\hline & $\begin{array}{c}20 \\
\text { menit } \\
\text { (f1) }\end{array}$ & $\begin{array}{c}40 \\
\text { menit } \\
\text { (f2) }\end{array}$ & $\begin{array}{c}60 \\
\text { menit } \\
\text { (f3) }\end{array}$ \\
\hline 3:7 (t1) & $3,77 \mathrm{~A}$ & $3,98 \mathrm{~A}$ & $3,99 \mathrm{~A}$ \\
\hline 1:1 (t2) & 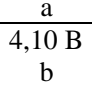 & $\begin{array}{c}\mathrm{a} \\
\begin{array}{c}3,97 \mathrm{~A} \\
\mathrm{a}\end{array}\end{array}$ & $\begin{array}{c}\mathrm{b} \\
3,92 \mathrm{~A} \\
\mathrm{a}\end{array}$ \\
\hline $7: 3(t 3)$ & $\begin{array}{c}4,42 \mathrm{C} \\
\mathrm{b}\end{array}$ & $\begin{array}{c}4,16 \mathrm{~B} \\
\mathrm{a}\end{array}$ & $\begin{array}{c}4,56 \mathrm{~B} \\
\mathrm{c}\end{array}$ \\
\hline
\end{tabular}

Keterangan : Huruf kecil dibaca arah horizontal dan huruf besar dibaca arah vertikal. Huruf yang berbeda menyatakan perbedaan yang nyata pada taraf 5\% uji Duncan.
Berdasarkan Tabel 7 respon panelis terhadap kerenyahan crackers menunjukkan nilai yang berkisar antara 3,77-4,56 yang artinya agak disukai panelis. Hasil penelitian menunjukkan semakin banyak perbandingan tepung ubi jalar oranye, kerenyahan crackers yang dihasilkan akan semakin tidak disukai oleh panelis.

Hasil penelitian menunjukkan bahwa semakin banyak perbandingan tepung talas yang ditambahkan menjadikan kerenyahan crackers memiliki nilai yang semakin tinggi, sedangkan penambahan perbandingan tepung ubi jalar oranye akan menghasilkan nilai kerenyahan yang rendah. . Hal ini disebabkan karena kadar amilosa dan amilopektin pada masing-masing tepung. Tepung talas mengandung amilosa 13,59\% dan amilopektin 69,92\% (Apriyani, dkk., 2011) sedangkan tepung ubi jalar oranye mengandung amilosa $38,85 \%$ dan amilopektin 61,15\% (Suryadinata,dkk., 2012)

Pati mempunyai peranan penting bagi pembuatan biskuit karena dapat mempengaruhi teksturnya. Pengaruh itu terutama disebabkan oleh rasio amilosa dan amilopektin dalam pati. Amilopektin diketahui bersifat merangsang terjadinya proses pengembangan (puffing), sehingga biskuit yang berasal dari pati dengan kandungan amilopektin yang cukup tinggi akan bersifat porus, garing dan renyah. Sebaliknya, pati dengan kandungan amilosa tinggi, misalnya pati yang berasal dari umbi-umbian, cenderung menghasilkan biskuit yang keras karena proses pengembangan terjadi secara terbatas (Muchtadi dan Ayustaningwarno, 2011).

\section{Karbohidrat}

Karbohidrat mempunyai peranan penting dalam menentukan karakteristik bahan makanan seperti rasa, warna dan tekstur. Karbohidrat merupakan sumber kalori utama walaupun jumlah kalori yang dihasilkan oleh 1 gram karbohidrat hanya $4 \mathrm{Kal}$ (kkal) bila disbanding protein dan lemak, selain itu beberapa golongan karbohidrat menghasilkan serat makanan (dietary fiber) yang berguna bagi pencernaan (Winarno, 2004).

Berdasarkan analisis variansi (ANAVA) dapat diketahui bahwa perbandingan tepung talas Bogor dengan tepung ubi jalar oranye $(\mathrm{T})$, waktu fermentasi $(\mathrm{F})$ dan interaksi keduanya (TF) tidak berpengaruh terhadap kadar karbohidrat, sehingga tidak dilakukan uji lanjut Duncan terhadap kadar karbohidrat crackers sayuran. Hasil analisis kadar karbohidrat crackers sayuran dapat dilihat pada Tabel 8.

Berdasarkan Tabel 8 dapat diketahui kadar karbohidrat crackers sayuran berkisar 57,853\% sampai $63,027 \%$. Kadar karbohidrat tertinggi yaitu pada perlakuan t1f2. Kadar karbohidrat pada seluruh crackers yang dihasilkan belum memenuhi standar kadar karbohidrat yang ditetapkan oleh SNI (1992) yaitu minimum 60\%. Menurut Passos et al. (2013), kandungan karbohidrat beberapa crackers komersial dapat mencapai $56,8-74,6 \%$. Kandungan karbohidrat pada crackers cukup tinggi karena bahan dasarnya berasal dari serealia dan adanya penambahan gula. 
Tabel 8. Hasil Analisis Kadar Karbohidrat Crackers Sayuran

\begin{tabular}{cc}
\hline Perlakuan & $\begin{array}{c}\text { Kadar } \\
\text { Karbohidrat } \\
(\%)\end{array}$ \\
\hline t1f1 (3:7, 20 menit) & 63.027 \\
\hline t1f2 (3:7, 40 menit) & 62.647 \\
\hline t1f3 (3:7, 60 menit) & 61.867 \\
\hline t2f1 (1:1, 20 menit) & 60.970 \\
\hline t2f2 (1:1, 40 menit) & 60.033 \\
\hline t2f3 (1:1, 60 menit) & 59.417 \\
\hline t3f1 (7:3, 20 menit) & 58.553 \\
\hline t3f2 (7:3, 40 menit) & 58.400 \\
\hline t3f3 (7:3, 60 menit) & 57.853 \\
\hline Riskiani,
\end{tabular}

Menurut Riskiani, dkk., (2014), nilai kadar karbohidrat pada crackers dipengaruhi oleh kandungan nutrisi bahan baku. Kandungan karbohidrat pada tepung talas Bogor adalah 85,75\% sedangkan kadar karbohidrat pada tepung ubi jalar oranye adalah $87.19 \%$

3. Lemak

Berdasarkan analisis variansi (ANAVA) dapat diketahui bahwa perbandingan tepung talas Bogor dengan tepung ubi jalar oranye $(\mathrm{T})$, waktu fermentasi $(\mathrm{F})$ dan interaksi keduanya (TF) tidak berpengaruh terhadap kadar lemak, sehingga tidak dilakukan uji lanjut Duncan terhadap kadar lemak crackers sayuran. Hasil analisis kadar lemak crackers sayuran dapatdilihat pada Tabel 9.

Tabel. 9 Hasil Analisis Kadar Lemak Crackers Sayuran

\begin{tabular}{cc}
\hline Perlakuan & $\begin{array}{c}\text { Kadar Lemak } \\
(\%)\end{array}$ \\
\hline t1f1 (3:7, 20 menit) & 11,42 \\
\hline t1f2 (3:7, 40 menit) & 11,92 \\
\hline t1f3 (3:7, 60 menit) & 10,42 \\
\hline t2f1 (1:1, 20 menit) & 11,87 \\
\hline t2f2 (1:1,40 menit) & 11,82 \\
\hline t2f3 (1:1,60 menit) & 11,88 \\
\hline t3f1 (7:3, 20 menit) & 12,84 \\
\hline t3f2 (7:3, 40 menit) & 12,69 \\
\hline t3f3 (7:3,60 menit) & 12,17 \\
\hline
\end{tabular}

Berdasarkan Tabel 9 dapat diketahui kadar lemak crackers sayuran berkisar 10,42\% sampai $12,84 \%$. Kadar lemak tertinggi yaitu pada perlakuan $\mathrm{t} 3 \mathrm{f} 1$. Kadar lemak pada seluruh crackers yang dihasilkan sudah memenuhi standar kadar lemak yang ditetapkan oleh SNI (1992) yaitu minimum $9,5 \%$.

Kandungan kadar lemak crackers sayuran dipengaruhi oleh kadar lemak dari bahan baku yaitu tepung talas Bogor dan tepung ubi jalar oranye. Kandungan lemak tepung talas Bogor yaitu sebesar 1,21 gram, sedangkan kadar lemak pada tepung ubi jalar oranye adalah 0,91 gram. Pengaruh terbesar kadar lemak berasal dari bahan tambahan seperti margarin turut menyumbangkan lemak pada biskuit (Widyastuti dkk, 2015).

\section{Protein}

Berdasarkan analisis variansi (ANAVA) dapat diketahui bahwa perbandingan tepung talas Bogor dengan tepung ubi jalar oranye $(\mathrm{T})$ berpengaruh terhadap kadar protein crackers sayuran sedangkan waktu fermentasi (F) dan interaksi keduanya (TF) tidak berpengaruh terhadap kadar protein, sehingga dilakukan uji lanjut Duncan terhadap kadar protein crackers sayuran. Hasil analisis kadar protein crackers sayuran dapat dilihat pada Tabel 10.

Tabel 10. Pengaruh Perbandingan Tepung Talas Bogor dengan Tepung Ubi Jalar Oranye Terhadap Kadar Protein Crackers Sayuran

\begin{tabular}{ccc}
\hline Perlakuan & Hasil Rata-Rata & $\begin{array}{c}\text { Taraf Nyata } \\
\mathbf{5 \%}\end{array}$ \\
\hline $\mathrm{t} 1(3: 7)$ & 10.981 & $\mathrm{a}$ \\
\hline $\mathrm{t} 2(1: 1)$ & 12.033 & $\mathrm{~b}$ \\
\hline $\mathrm{t} 3(7: 3)$ & 13.949 & $\mathrm{c}$
\end{tabular}

Keterangan: Nilai rata-rata yang ditandai dengan huruf yang sama menunjukkan tidak berbeda nyata pada taraf 5\% Uji Duncan.

Berdasarkan Tabel 10 menunjukkan bahwa semakin banyak perbandingan tepung ubi jalar oranye yang ditambahkan semakin rendah kadar protein pada crackers sayuran. Pernyataan ini sesuai dengan penelitian (Widyastuti., dkk, 2015) semakin banyak penambahan tepung ubi jalar oranye maka kadar protein akan semakin menurun, hal ini dikarenakan jumlah kandungan protein pada bahan baku tepung ubi jalar oranye rendah.

Kadar protein pada seluruh crackers yang dihasilkan berkisar $10,72 \%$ sampai $14,08 \%$ sehingga sudah memenuhi standar kadar protein yang ditetapkan oleh SNI (1992), yaitu minimum 9\%. Menurut Passos et al. (2013), kandungan protein beberapa biskuit dan crackers komersial dapat mencapai 3-14,6\%.

5. Air

Berdasarkan analisis variansi (ANAVA) dapat diketahui bahwa perbandingan tepung talas Bogor dengan tepung ubi jalar oranye $(\mathrm{T})$ berpengaruh terhadap kadar air crackers sayuran sedangkan waktu fermentasi (F) dan interaksi keduanya (TF) tidak berpengaruh terhadap kadar air, sehingga dilakukan uji lanjut Duncan terhadap kadar air crackers sayuran. Hasil analisis kadar air crackers sayuran dapat dilihat pada Tabel 11.

Berdasarkan Tabel 11 menunjukkan bahwa semakin banyak perbandingan tepung ubi jalar oranye yang ditambahkan semakin tinggi kadar air pada crackers sayuran. Pernyataan ini sesuai dengan penelitian pendahuluan, kandungan kadar air pada tepung ubi jalar oranye lebih tinggi dibandingkan tepung talas Bogor yaitu 6,5\% sedangkan kandungan air tepung talas Bogor adalah $4,97 \%$. 
Tabel 11. Pengaruh Perbandingan Tepung Talas Bogor dengan Tepung Ubi Jalar Oranye Terhadap Kadar Air Crackers Sayuran

\begin{tabular}{ccc}
\hline Perlakuan & Hasil Rata-Rata & Taraf Nyata 5\% \\
\hline $\mathrm{t} 1(3: 7)$ & 4.979 & $\mathrm{c}$ \\
\hline $\mathrm{t} 2(1: 1)$ & 4.704 & $\mathrm{~b}$ \\
\hline $\mathrm{t} 3(7: 3)$ & 4.215 & $\mathrm{a}$
\end{tabular}

Keterangan: Nilai rata-rata yang ditandai dengan huruf yang sama menunjukkan tidak berbeda nyata pada taraf 5\% Uji Duncan.

Kadar air pada seluruh crackers yang dihasilkan berkisar 4,03\% sampai $5.04 \%$ sehingga masih belum memenuhi standar kadar air yang ditetapkan oleh SNI (1992), yaitu maksimum 5\%. Kadar air sangat mempengaruhi daya tahan bahan makanan terhadap serangan mikroba yang bisa merusak bahan makanan tersebut. Khusus untuk produk-produk biskuit sangat erat kaitannya dengan sifat kerenyahannya (Artama, 2001).

\section{Serat}

Berdasarkan analisis variansi (ANAVA) dapat diketahui bahwa perbandingan tepung talas Bogor dengan tepung ubi jalar oranye $(\mathrm{T})$ berpengaruh terhadap kadar serat crackers sayuran sedangkan waktu fermentasi (F) dan interaksi keduanya (TF) tidak berpengaruh terhadap kadar serat, sehingga dilakukan uji lanjut Duncan terhadap kadar serat crackers sayuran. Hasil analisis kadar serat crackers sayuran dapat dilihat pada Tabel 12 .

Tabel 12. Pengaruh Perbandingan Tepung Talas Bogor dengan Tepung Ubi Jalar Oranye Terhadap Kadar Serat Crackers Sayuran

\begin{tabular}{ccc}
\hline Perlakuan & Hasil Rata-Rata & $\begin{array}{c}\text { Taraf } \\
\text { Nyata 5\% }\end{array}$ \\
\hline $\mathrm{t} 1(3: 7)$ & 4.533 & $\mathrm{c}$ \\
\hline $\mathrm{t} 2(1: 1)$ & 6.088 & $\mathrm{~b}$ \\
\hline $\mathrm{t} 3(7: 3)$ & 7.240 & $\mathrm{a}$ \\
\hline
\end{tabular}

Keterangan: Nilai rata-rata yang ditandai dengan huruf yang sama menunjukkan tidak berbeda nyata pada taraf 5\% Uji Duncan.

Berdasarkan Tabel 12 menunjukkan bahwa semakin banyak perbandingan tepung ubi jalar oranye yang ditambahkan semakin tinggi kadar serat pada crackers sayuran. Kadar serat pada seluruh crackers yang dihasilkan berkisar 4,36\% sampai 7,38\%. Kadar serat pada crackers sayuran tidak memenuhi standar kadar serat yang ditetapkan oleh SNI (1992), yaitu maksimum $0,5 \%$.

Hasil analisis menunjukkan bahwa perbandingan tepung talas Bogor dengan tepung ubi jalar oranye serta penambahan wortel dan seledri meningkatkan serat pada crackers sayuran. Pernyataan ini didukung penelitian Friska dan Setiawan, (2002) crackers dengan penambahan serbuk wortel memiliki kadar serat sebesar $15 \%$ serat makanan (A3B3) mengandung 12,01 gram serat makanan per 100 gram crackers.

Serat pangan (dietary fiber) merupakan polisakarida yang tidak dapat dicerna/dihidrolisis oleh enzim pencernaan manusia dan sampai ke dalam usus besar dalam keadaan utuh. Senyawa pektin, hemiselulosa, dan selulosa merupakan serat pangan yang terdapat pada ubi jalar dan berperan dalam menentukan nilai gizinya. Kadar serat pangan pada ubi jalar cukup tinggi, yakni 2,3 sampai dengan 3,3 g/100 g bb. Asupan serat pangan dianjurkan 25 g/hari. Konsumsi 100 g ubi jalar memenuhi $8 \%$ angka kecukupan asupan tersebut (Ginting, 2011).

Menurut Departemen Kesehatan (2013), Angka kecukupan gizi serat untuk kelompok umur 0-6 bulan adalah 0 gram, kelompok umur 7-11 bulan adalah 10 gram, kelompok umur 1-3 tahun adalah 16 gram, kelompok umur 4-6 tahun adalah 22 gram, kelompok umur 7-9 tahun adalah 26 gram, kelompok remaja adalah 30-37 gram, kelompok dewasa adalah 38 gram dan kelompok lansia adalah 20-22 gram.

Kandungan serat pada crackers sayuran ini cukup tinggi sehingga dapat dijadikan sebagai pangan fungsional yang dapat memenuhi kebutuhan asupan serat pangan masyarakat.

7. Abu

Kadar abu merupakan parameter untuk menunjukkan nilai kandungan bahan anorganik (mineral) yang ada di dalam suatu bahan atau produk. Semakin tinggi nilai kadar abu maka semakin banyak kandungan bahan organik di dalam produk tersebut. Komponen bahan anorganik di dalam suatu bahan sangat bervariasi baik jenis maupun jumlahnya. Kandungan bahan anorganik yang terdapat di dalam suatu bahan diantaranya kalsium, kalium, fosfor, besi, magnesium, dan lain-lain (Sudarmadji, 2010).

Berdasarkan analisis variansi (ANAVA) dapat diketahui bahwa perbandingan tepung talas Bogor dengan tepung ubi jalar oranye $(\mathrm{T})$ berpengaruh terhadap kadar abu crackers sayuran sedangkan waktu fermentasi (F) dan interaksi keduanya (TF) tidak berpengaruh terhadap kadar abu. Sehingga dilakukan uji lanjut Duncan terhadap kadar abu crackers sayuran. Hasil analisis kadar abu crackers sayuran dapat dilihat pada Tabel 13.

Tabel 13. Pengaruh Perbandingan Tepung Talas Bogor dengan Tepung Ubi Jalar Oranye Terhadap Kadar Abu Crackers Sayuran

\begin{tabular}{ccc}
\hline Perlakuan & Hasil Rata-Rata & $\begin{array}{c}\text { Taraf Nyata } \\
\mathbf{5 \%}\end{array}$ \\
\hline $\mathrm{t} 1(3: 7)$ & 1.43 & $\mathrm{a}$ \\
\hline $\mathrm{t} 2(1: 1)$ & 1.52 & $\mathrm{a}$ \\
\hline $\mathrm{t} 3(7: 3)$ & 1.91 & $\mathrm{~b}$ \\
\hline
\end{tabular}

Keterangan: Nilai rata-rata yang ditandai dengan huruf yang sama menunjukkan tidak berbeda nyata pada taraf 5\% Uji Duncan.

Berdasarkan Tabel 13 menunjukkan bahwa semakin banyak perbandingan tepung talas Bogor yang ditambahkan semakin tinggi kadar abu pada crackers sayuran. Pernyataan ini didukung oleh penelitian Pangaribuan., dkk (2013) semakin tinggi konsentrasi 
tepung talas Belitung yang digunakan dalam pembuatan biskuit, kadar abunya semakin meningkat. Kadar abu pada seluruh crackers yang dihasilkan berkisar 1,33\% sampai $1,92 \%$. Kadar abu pada crackers sayuran sudah memenuhi standar kadar abu yang ditetapkan oleh SNI (1992), yaitu maksimum $2 \%$.

\section{Respon Sampel Terpilih}

Hasil analisis variansi (ANAVA) menunjukkan bahwa perlakuan t2f1 yaitu perlakuan perbandingan tepung talas Bogor dengan tepung ubi jalar oranye $(\mathrm{T})$ yaitu 1:1 dengan waktu fermentasi (F) 20 menit merupakan produk terpilih untuk digunakan analisis kadar beta karoten, berdasarkan produk yang memenuhi (SNI 01-2973-1992) perlakuan t2f1 lebih disukai panelis dari segi warna, aroma, rasa, dan kerenyahan serta memiliki kadar air terkecil yaitu 4,58\%.

Betakaroten merupakan komponen yang paling penting dalam makanan yang berwarna jingga. Beta karoten terdiri atas dua grup retinil, yang di dalam mukosa usus kecil akan dipecah oleh enzim betakaroten dioksigenase menjadi retinol, yaitu sebuah bentuk aktif dari vitamin A. Karoten dapat disimpan dalam bentuk provitamin A dan akan diubah menjadi vitamin A sesuai kebutuhan (Astawan, 2008).

Berdasarkan hasil analisis kadar betakaroten pada perlakuan produk menggunakan instrument sprektofotometri UV-Vis, didapat bahwa crackers sayuran perlakuan t2f1 memiliki kadar betakaroten sebesar 19,3902 ppm atau sebesar 19,3902 mg/100 gram. Menurut Balitkabi (2012), Ubi jalar oranye varietas Beta 1 mengandung $\beta$-karoten sebanyak $12.032 \mu \mathrm{g} / 100$ gram. Hasil analisis kadar betakaroten yang dilakukan mempunyai kandungan yang lebih rendah dibandingkan dengan literatur.

Faktor-faktor yang dapat mempengaruhi kandungan betakaroten yakni varietas, suhu pengeringan, serta tingkat kematangan Menurut Histifarina dkk., (2004), degradasi karoten yang terjadi selama pengolahan diakibatkan oleh proses oksidasi pada suhu tinggi yang mengubah senyawa karoten menjadi senyawa ionon berupa keton. Senyawa karotenoid mudah teroksidasi terutama pada suhu tinggi yang disebabkan oleh adanya sejumlah ikatan rangkap dalam struktur molekulnya.

Banyak faktor lain yang dapat mempengaruhi kestabilan karoten. Legowo (2005), menyebutkan bahwa karoten stabil pada $\mathrm{pH}$ netral, alkali namun tidak stabil pada kondisi asam, adanya udara atau oksigen, cahaya dan panas. Karotenoid tidak stabil karena mudah teroksidasi oleh adanya oksigen dan peroksida.

Berdasarkan hasil penelitian, dapat diambil kesimpulan sebagai berikut.

1. Hasil Penelitian pendahuluan menunjukkan kadar oksalat talas Bogor sebesar 56,14 mg/gram, kadar oksalat tepung talas Bogor sebesar 8,69 mg/gram, kadar air tepung talas Bogor sebesar 4,97\%. Kadar air tepung ubi jalar oranye sebesar $6,5 \%$. Peak Viscosity Amilogram tepung campuran 1:1 menunjukan suhu gelatinisasi sebesar 94oC, dengan waktu 5 menit. Berdasarkan hasil pengujian organoleptik pada penelitian pendahuluan, formula yang terpilih adalah formula 3 (f3), yang digunakan untuk penelitian utama. Formula 3 terdiri dari tepung talas $20 \%$, tepung ubi jalar $20 \%$, lemak nabati $10 \%$, ragi $1,5 \%$, baking powder $1 \%$, gula jagung $1,2 \%$,garam $0,6 \%$, susu beras $12 \%$, wortel $12,3 \%$, daun seledri $5,5 \%$, ikan lele $15,9 \%$.

2. Perbandingan tepung talas Bogor dengan tepung ubi jalar oranye berpengaruh terhadap mutu crackers sayuran meliputi respon kimia yaitu kadar protein, kadar air, kadar serat dan kadar abu serta respon organoleptik yaitu berpengaruh terhadap atribut warna, aroma, rasa, dan kerenyahan tetapi tidak berpengaruh terhadap kadar karbohidrat dan kadar lemak.

3. Waktu fermentasi berpengaruh terhadap mutu crackers sayuran meliputi respon organoleptik yaitu aroma dan kerenyahan tetapi tidak berpengaruh terhadap warna dan rasa serta respon kimia yaitu kadar karbohidrat, kadar lemak, kadar protein, kadar air, kadar abu, dan kadar serat.

4. Interaksi Perbandingan tepung talas Bogor dengan tepung ubi jalar oranye dan waktu fermentasi berpengaruh terhadap mutu crackers sayuran meliputi respon organoleptik yaitu aroma dan kerenyahan tetapi tidak berpengaruh terhadap warna dan rasa serta respon kimia yaitu kadar karbohidrat, kadar lemak, kadar protein, kadar air, kadar abu, dan kadar serat.

5. Berdasarkan tabel ANAVA pada pengujian organoleptik dan analisis kimia penelitian utama didapatkan produk terpilih yaitu pada perlakuan $\mathrm{t} 2 \mathrm{f} 1$ (perbandingan tepung talas Bogor dengan tepung ubi jalar oranye (1:1) dan waktu fermentasi 20 menit) dengan nilai rata-rata warna sebesar 3,80, aroma sebesar 4,00, kerenyahan sebesar 4,10, rasa sebesar 3,80 , kadar air sebesar 4,58\%, kadar abu sebesar $1,5 \%$, kadar lemak sebesar $11,87 \%$, kadar protein sebesar 11,82\%, kadar karbohidrat sebesar 60,97\%, kadar serat sebesar 6,19\% dan kadar betakaroten sebesar 19,3902 mg/100gram

\section{Daftar Pustaka}

1. Amalia, R. Dan R.Yuliana. 2013. Studi Pengaruh Perendaman Dan Perebusan Terhadap Kandungna Kalsium Oksalat Pada Umbi Senthe. Jurnal Teknologi Kimia dan Industri Vol.2 No. 3 hal 17-23. Universitas Dipenogoro

2. AOAC. 1995. Official Methods of Analysis of The Association of The Official Analytical Chemist, Edisi ke 1, AOAC, Inc. Washington D. C., USA.

3. AOAC. 2005. Official Methods of Analysis of The Association of The Official Analytical Chemist. Washington D. C., USA. 
4. AOAC. 2010. Official Methods of Analysis of The Association of The Official Analytical Chemist. Washington D. C., USA.

5. Artama, T. 2001. Pemanfaatan Tepung Ikan Lemuru (Sardinella longiceps) Untuk Meningkatkan Mutu Fisik dan Nilai Gizi Crackers. Tesis. Program Pasca Sanjana. Institut Pertanian Bogor. Bogor.

6. Astawan, M. 2008. Sehat dengan Hidangan Hewani. Penebar Swadaya. Jakarta

7. Badan Standarisasi Nasional. 1992. SNI 01-29731992. Syarat Mutu dan Cara Uji Biskuit. Badan Standarisasi Nasional : Jakarta

8. Balai Penelitian Tanaman Kacang-kacangan dan Umbi-umbian (Balitkabi). 2012. Deskripsi Varietas Kacang-Kacangan dan Umbi-Umbian. Pusat Penelitian dan Pengembangan Tanaman Pangan. Malang.

9. BPS. 2008. Statistik Indonesia. Badan Pusat Statistik Indonesia, Jakarta

10. Chotimah, S. dan D.S. Fajarini. 2013. Reduksi Kalsium Oksalat Dengan Perebusan Menggunakan Larutan $\mathrm{NaCl}$ dan Penepungan Meningkatkan Kualitas Senthe Sebagai Bahan Pangan. Jurnal Teknologi Kimia dan Industri Vol.2 No.2 Hal 76-83. Universitas Dipenogoro

11. Darajat, D. P., W.H. Susanto \& I. Purwatiningrum. 2014. Pengaruh Umur Fermentasi Tempe Dan Proporsi Dekstrin Terhadap Kualitas Susu Tempe Bubuk. Jurnal Pangan dan Agroindustri, 2(1), 47-53

12. Deman, J.M. 1997. Kimia Makanan, Edisi Kedua. Bandung : Institur Teknologi Bandung.

13. Departemen Perindustrian RI. 1990. Crackers dan Cookies. Jakarta.

14. Direktorat Gizi Departemant Kesehatan RI. 1981. Daftar Komposisi Bahan Makanan. Jakarta : Bhrata Karya Aksara.

15. Fardiaz, D., A.Apriyantono., N.L.Puspitasari., B.S. Sedarnawati, dan S. Budiyanto. 1989. Petunjuk Laboratorium Analisis Pangan. Bogor : Pusat Antar Universitas Pangan dan Gizi. Institut Pertanian Bogor.

16. Fellows, P.J. 1998. Food Processing Technology, Principle ans Practice. Second Edition. CRC Press, England

17. Friska, T. dan B.Setiawan. 2002. Penambahan Sayur Bayam, Sawi, dan Wortel Pada Pembuatan Crackers Tinggi Serat Makanan. Bogor : Institut Pertanian Bogor

18. Ginting, Sadar., (2010). Pemanfaatan Ubi Jalar Orange sebagai Bahan Pembuat Biskuit untuk Alternatif Makanan Tambahan Anak Sekolah Dasar di Desa Ujung Bawang Kecamatan Dolok Silau Kabupaten Simalungun. Universitas Sumatera Utara : Medan

19. Hamidah, S. dan Purwanti, S. 2009. Patiseri. Yogyakarta : Jurusan PTBB FT Universitas Negeri Yogyakarta.
20. Hartati, N.S. dan T.K. Prana. 2003. Analisis Kadar Pati Dan Serat Kasar Tepung Beberapa Kultivar Talas. Jurnal Natur Indonesia, 6(1), 29-33.

21. Histifarina,D., D. Musaddad, dan E.Murtiningsih. 2004. Teknik Pengeringan Dalam Oven untuk Irisan Wortel Keirng Bermutu. Jurnal Volume 14. Balai Penenlitian Tanaman dan Sayuran.

22. Kafah, F.F.S., Y.A. Purwanto, dan D.Nuraini. 2012. Karakteristik Tepung Talas (Colocasia esculenta (L) Schott) dan Pemanfaatannya dalam Pembuatan Cake. Bogor. Institut Pertanian Bogor.

23. Kartika, B., Pudji H., dan Wahyu S. 1987. Pedoman Uji Inderawi Bahan Pangan. Yogyakarta : Universitas Gajah Mada.

24. Kurdi W. 2002. Reduksi Kalsium Oksalat pada Talas Bogor (Colocasia esculenta (L.) Schott) sebagai Upaya Meningkatkan Mutu Keripik Talas. IPB, Bogor

25. Legowo, A.M. 2005. Diversifikasi Produk Olahan dengan Bahan Baku Susu. Semarang. Fakulltas Peternakan. Universitas Dipenogoro.

26. Maulina, F.D.A., I.M. Lestari., dan D.S. Retnowati. 2012. Pengurangan Kadar Kalsium Oksalat Pada Umbi Talas Menggunakan Nahco3 Sebagai Bagan Dasar Tepung. Jurnal Teknik Kimia dan Industri Vol. 1 No.1 hal 278. Universitas Dipenogoro.

27. Manoppo, S., E. Ishak, dan J. Langkong. 2012. Studi Pembuatan Crackers Dengan Sukun (Artocarpus Communis) Pragelatinisasi.Universitas Hasanudin

28. Muchtadi, T. R. dan F. Ayustaningwarno. 2011. Teknologi Proses Pengolahan Pangan. IPB : Bogor

29. Onwueme, I.C. 1978. Strategies for increasing cocoyam (Colocasia Xanthosoma sp), In Nigeria Food Basket paper Presented at the First National Workshop on Cocoyam NRCRI-Umudike, Nigeria.

30. Pangaribuan. A.D., L.M.E. Purwijantiningsih, dan F.S. Pranata. 2013. Substitusi Tepung Talas Belitung Pada Pembuatan Biskuit Daun Kelor (Moringa Oleifera Lamk). Yogyakarta : Universitas Jaya Yogyakarta

31. Passos, M.E.A., Moreira, C.F.F., Pacheco, M.T.B., Takase, I., Lopes, M.L.M., Valente Mesquita, V.L. 2013. Proximate and Mineral Composition of Industrialized Biscuits. Food Science and Technology, Campinas, 33(2):323-3331

32. Purwanto, C. C., Ishartani, D., dan Rahadian, D. 2013. Kajian Sifat Fisik dan Kimia Tepung Labu Kuning (Curcubita maxima) dengan Perlakuan Blanching dan Perendaman Natrium Metabisulfit (Na2S2O3). Jurnal Teknosains Pangan. Jurusan Teknologi Hasil Pertanian. Universitas Sebelas Maret Vol. 2 (2).

33. Rekha, M.R. dan G. Padmaja. 2002. Alpha-Amylase Inhibitor Changes During Processing Of Sweet Potato And Taro Tubers. Plant Food for Human Nutrition 52: 285-294 Menuju Perdagangan Bebas, 39 497-502. 
34. Richana, N. 2012. Araceae \& Dioscorea : Manfaat Umbi-umbian Indonesia. Bandung : Nuansa.

35. Riskiani, dkk., 2004. Pemanfaatan Tepung Umbi Ganyong (Canna Edulis Ker.) Sebagai Pengganti Tepung Terigu Dalam Pembuatan Biskuit Tinggi Energi Protein Dengan Penambahan Tepung Kacang Merah (Phaseolus Vulgaris L.). Jurnal Teknosains Pangan. Vol 3 No 1 Januari 2014.

36. Setyawan,B. 2015. Budidaya Umbi-Umbian Padat Nutrisi. Yogyakarta: Pustaka Baru Press

37. Standar Nasional Indonesia. 1992. Syarat Mutu Biskuit. Departemen Perinduustrian RI

38. Sudarmadji, S., Haryono, B., dan Suhardi. 2010. Analisa Bahan Makanan dan Pertanian. Liberty : Yogyakarta

39. Suryadinata, O.M., S. Ristiarini dan M.I. Epriliati. Pengaruh Proporsi Tepung Ubi Jalar Kuning Dan Tepung Terigu Terhadap Sifat Fisikokimia Dan Organoleptik Biskuit Manis. Surabaya : Fakultas Teknologi Pertanian, Universitas Katolik Widya Mandala Surabaya.

40. Widyastuti, E., R. Claudia., T.Estiasih, dan D.W.Ningtyas. 2015. Karakteristik Biskuit Berbasis Tepung Ubi Jalar Oranye (Ipomoea Batatas L.), Tepung Jagung (Zea mays) Fermentasi dan Konsentrsi Kuning Telur. Jurnal Teknologi Pertanian Vol 16 No. 1 April 2015 (9-20).

41. Winarno, F. G. 2004. Kimia Pangan dan Gizi. Jakarta : PT. Gramedia Pustaka Utama. 